\title{
Bedding-parallel calcite veins in the Holy Cross Mountains Fold Belt, central Poland
}

\author{
Barbara RYBAK-OSTROWSKA ${ }^{1, *}$, Andrzej KONON ${ }^{1}$, Krzysztof NEJBERT $^{1}$ and Andrzej KOZŁOWSKI ${ }^{1}$ \\ 1 Faculty of Geology, University of Warsaw, Żwirki i Wigury 93, 02-089 Warszawa, Poland
}

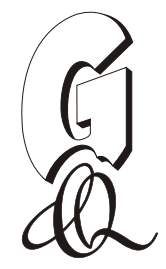

Rybak-Ostrowska B., Konon A., Nejbert K. and Kozłowski A. (2014) Bedding-parallel calcite veins in the Holy Cross Mountains Fold Belt, central Poland. Geological Quarterly, 58 (1): 99-116, doi: 10.7306/gq.1136

\begin{abstract}
Bedding-parallel calcite veins in Devonian rocks from the southern part of the Holy Cross Mountains Fold Belt in central Poland occur as tabular bodies on shallow-dipping as well as vertical Late Paleozoic map-scale and mesoscopic fold limbs. The syntaxial and antitaxial bedding-parallel veins contain kinematic indicators such as rotated blocks, fibre boundary steps, boudin trains, beef-like structures and congruous steps. These structures show a sense of movement consistent with the flexural slip typical of folding resulting from buckling during subhorizontal shortening. We propose a mechanism of the gradual formation of the veins and a progressive fabric development which is mostly consistent with an increasing dip angle of the fold limbs and their gradual deformation. The fabric of the veins and kinematic indicators within the veins point to the syntectonic growth of calcite during the Late Paleozoic buckle folding in the Holy Cross Mountains Fold Belt.
\end{abstract}

Key words: bedding-parallel calcite veins, kinematic indicators, flexural slip, horizontal shortening, Late Paleozoic buckle folding, Holy Cross Mountains Fold Belt.

\section{INTRODUCTION}

Bedding-parallel veins are useful tools in determining mechanisms of fold growth and deformation history. As such, they have been the subject of investigations in orogenic belts and in non-folded regions. Bedding-parallel veins are common in sedimentary and low-grade metamorphic rocks (Tanner, 1989; Price and Cosgrove, 1990; Roo and Weber, 1992; Jessell et al., 1994; Fowler, 1996; Cobbold et al., 2013 and references therein). Studies on bedding-parallel veins have shown that they may indicate high pressure pore-fluid circulation (Cosgrove, 1993; Suchy et al., 2002; Hilgers et al., 2006) that partly resulted from hydrocarbon generation (Cobbold and Rodrigues, 2007; Rodrigues et al., 2009). Bedding-parallel veins have been used to obtain information on the crystal growth mechanism, its significance in the deformation process and relationship to displacement paths (Durney and Ramsay, 1973; Ramsay, 1980; Cox and Etheridge, 1983; Cox, 1987; Passchier and Trouw, 1996; Petit et al., 1999; Koehn and Passchier, 2000; Means and Li, 2001; Hilgers and Urai, 2002b; Bons and Montenari, 2005). In addition, comprehensive structural analysis combined with petrographic and geochemical studies allow to establish the relationship between fluids and tectonic structures (Kenis et al., 2000; Lee and Wiltschko, 2000; Sejourne et al., 2005; Hilgers et al., 2006; Wiltschko et al., 2009; Note et al., 2011).

\footnotetext{
* Corresponding author, e-mail: Barbara.Rybak@uw.edu.pl
}

Received: June 28, 2013; accepted: October 22, 2013; first published online: December 2, 2013
The aim of this paper is to present a model for the origin of bedding-parallel veins occurring in sedimentary rocks from the southern part of the Holy Cross Mountains (HCM; Fig. 1), based on field observations coupled with petrographic and geochemical studies. Tectonic field studies and microstructural analysis of the veins have been performed to determine kinematic characteristics of the veins and correlate their development with flexural slip during folding.

\section{GEOLOGICAL SETTING}

The HCM Fold Belt is located within the broad NW-SE-trending Trans-European Suture Zone, which separates the East European Craton from the younger fold-belts of Central Europe (Berthelsen, 1993). The fold belt comprises a series of map-scale folds built of Paleozoic rocks and is divided into two parts - the Łysogóry Fold Zone (to the north) and the Kielce Fold Zone (to the south; Fig. 1; Czarnocki, 1919, 1938, 1957a; Pożaryski, 1978; Konon, 2008). The zones are separated by the Holy Cross Fault (HCF), at least $75 \mathrm{~km}$ long (Czarnocki, 1938). The geodynamic position of the HCM is still a matter of discussion. The fold zones are considered to be two different tectono-stratigraphic units because their rock sequences can be distinguished from each other by lithology and depositional environment (Czarnocki, 1919, 1957a; Pożaryski, 1978; Fig. 2). The boundary between the Kielce and Łysogóry Fold zones is interpreted as the boundary between the Małopolska and Łysogóry terranes (e.g., Pożaryski et al., 1992; Pożaryski and Tomczyk, 1993; Unrug et al., 1999). These terranes are considered to be the first tectonic blocks that accreted to Baltica between late Middle Cambrian and Tremadocian times (Belka et al., 2002). The rock sequence forming the Małopolska Terrane consists of Vendian to Tremadocian de- 


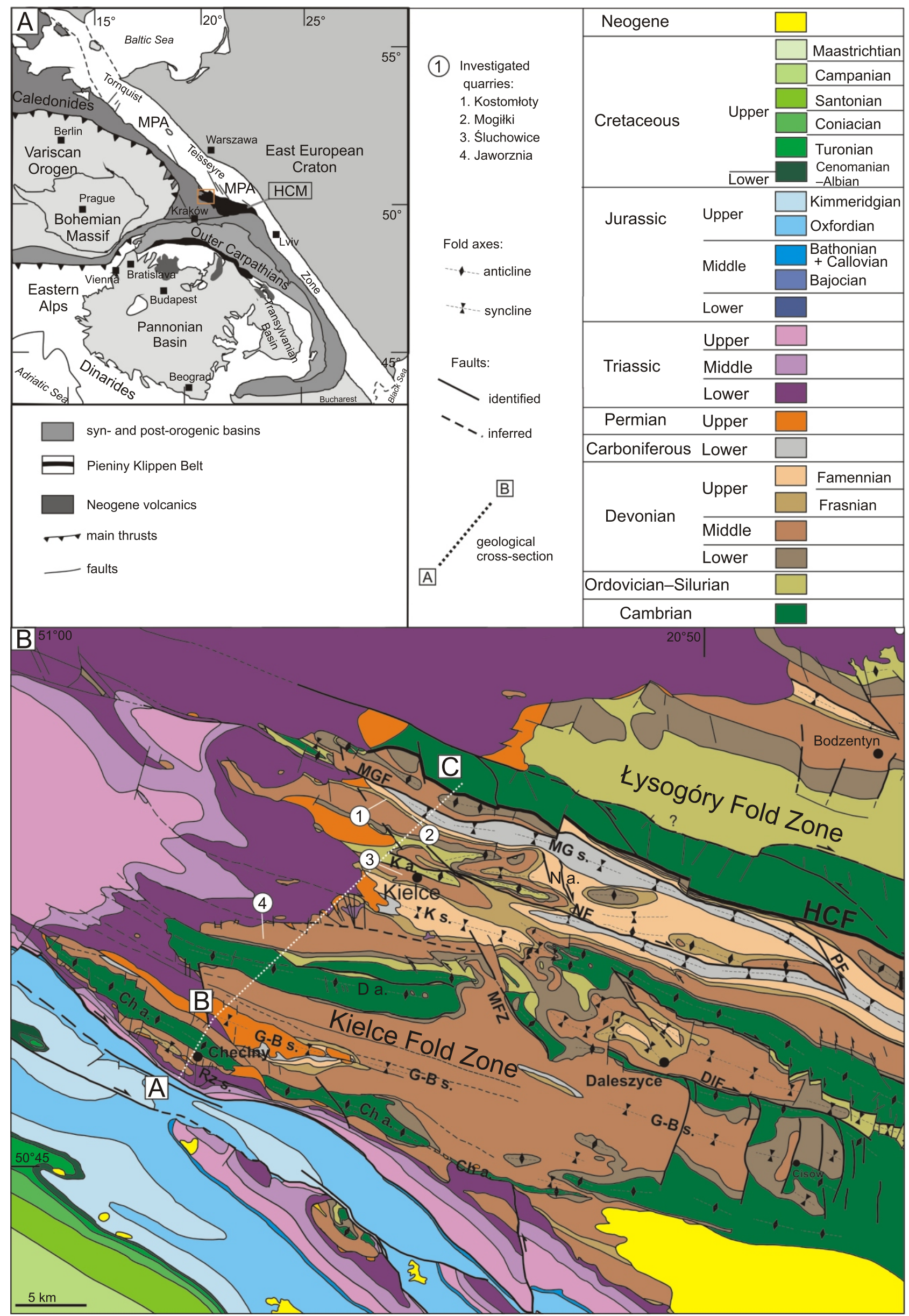



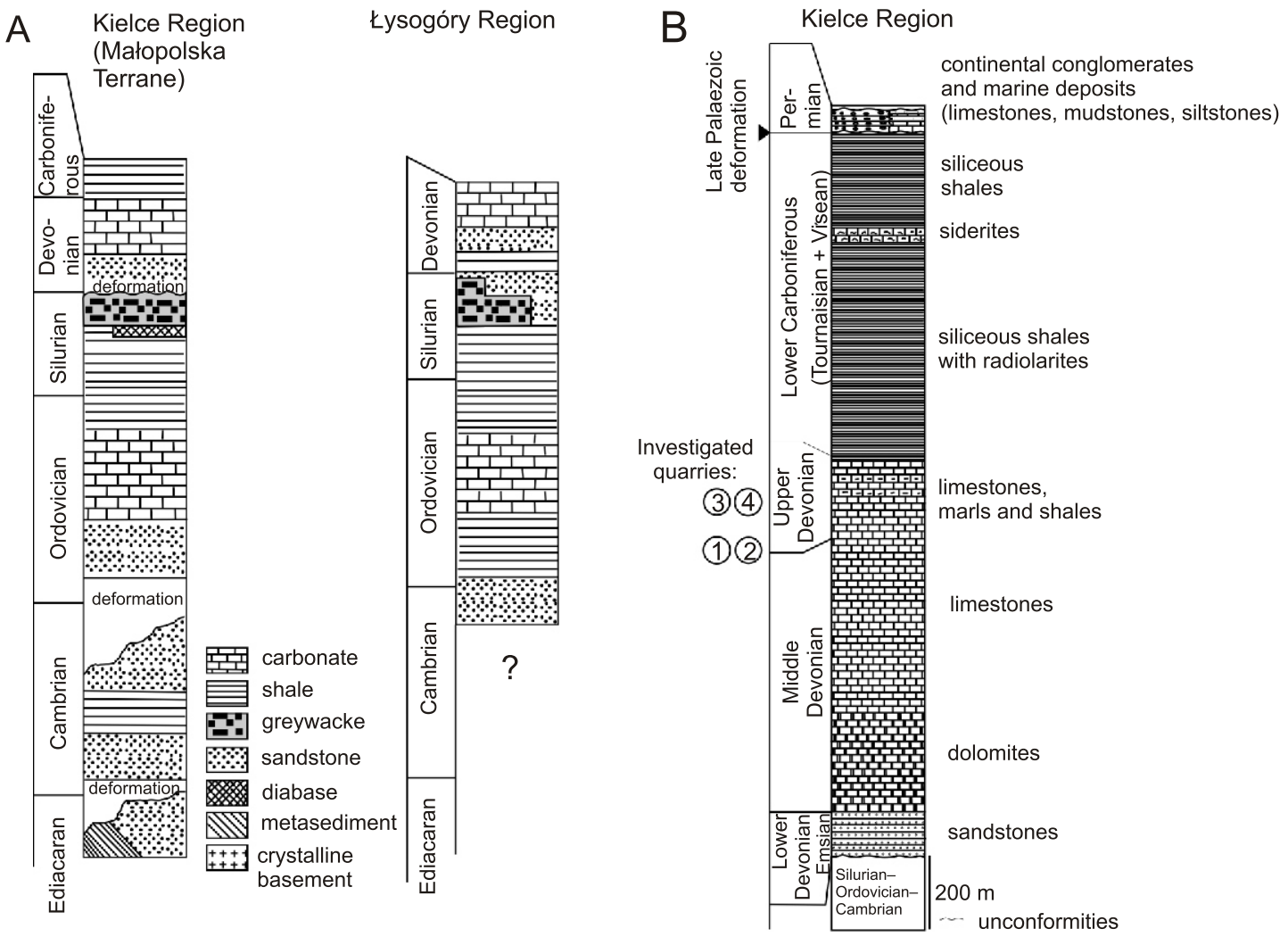

Fig. 2A - lithostratigraphic columns of strata in the Kielce and Kysogóry regions (based on Nawrocki and Poprawa, 2006, slightly modified); B - lithostratigraphic column of strata in the Paleozoic core of the Kielce Region (based on Hakenberg et al., 1976; Stupnicka, 1992 and references therein)

posits, which are covered by Floian (Lower Ordovician) to Neogene clastic and carbonate rocks (for review see Unrug et al., 1999; Belka et al., 2002; Nawrocki and Poprawa, 2006). Five unconformities have been recognized in this sequence: between the Ediacaran and Cambrian, between the Cambrian and Ordovician, between the Silurian and Devonian, between the Carboniferous and Permian, and between the Cretaceous and Neogene, interpreted as the results of tectonic deformation (e.g., Unrug et al., 1999; Nawrocki and Poprawa, 2006). In the Łysogóry Terrane the rock sequence comprises Middle Cambrian to Devonian siliciclastic and carbonate rocks, which are unconformably covered by Permian and younger rocks (e.g., Czarnocki, 1919, 1938).

Rocks of the Łysogóry and Kielce regions were folded together after the Visean during Late Carboniferous times (Czarnocki, 1919, 1938, 1950, 1957a, b; Lewandowski, 1982, 1985; Tomczyk, 1988; Szulczewski, 1995; Lamarche et al., 1999, 2002; Konon, 2006; Szaniawski, 2008; Szaniawski et al., 2011). This stage of deformation resulted in the formation of the HCM Fold Belt eastwards of the Variscan Orogen thrust front (Pożaryski et al., 1992; Dadlez et al., 1994; Mizerski, 1995;
Szulczewski, 1995; Krzemiński, 1999; Jaworowski, 2002; Mazur et al., 2006; Konon, 2007). The shortening direction during the folding was NNE-SSW (Czarnocki, 1938, 1950, 1957a, b, 1961a-f; Konon, 2006, 2007).

The generally WNW-SSE-trending folds from the southern part investigated of the HCM belt (Fig. 3), south of the HCF, exhibit distinct variations in wavelength range of 1.5 to $8 \mathrm{~km}$ and in amplitude range of 0.2 to $0.8 \mathrm{~km}$ (Konon, 2006). The geometry of the fold shape profiles is variable. The folds may be symmetrical or asymmetrical. Geometries of the fold shape profiles commonly change along their axes (Czarnocki, 1956; Filonowicz, 1967, 1968; Kutek and Głazek, 1972; Hakenberg, 1973; Kowalski, 1975; Konon, 2006). During the Late Paleozoic fold growth, layer-parallel shortening and layer-parallel shearing resulted in the development of different mesostructures, such as minor contractional duplexes, contraction and extension fault sets, stylolites, boudinage and cleavage on the fold limbs (Konon, 2006). The fold shape profiles that formed mainly during the Late Carboniferous were slightly modified in Maastrichtian-Paleocene times (Kutek and Głazek, 1972; Lewandowski, 1982, 1985; Szaniawski, 2008; Szaniawski et al., 2011).

Fig. 1A - tectonic sketch-map of Central Europe (simplified after Janik et al., 2009), red square in the middle is Figure 1B; B - geological map of the Holy Cross Mountains (after Czarnocki, 1938, 1961a-f; Filonowicz, 1973; Konon, 2007, modified)

MPA - Mid-Polish Anticlinorium, HCM - Holy Cross Mountains; folds in the Kielce Fold Zone (from the north): MG s. - Miedziana Góra Syncline, N a. - Niewachlów Anticline, K a. - Kielce Anticline, K s. - Kielce Syncline, D a. - Dyminy Anticline, G-B s. - Gałęzice-Bolechowice Syncline, Ch a. - Chęciny Anticline, Rz s. - Rzepka Syncline; main faults in the Holy Cross Mountains (from the north): HCF - Holy Cross Fault, MGF - Miedziana Góra Fault, NF - Niewachlów Fault, PF - Porąbki Fault, MFZ - Mójcza Fault Zone, DIF - Daleszyce Fault 


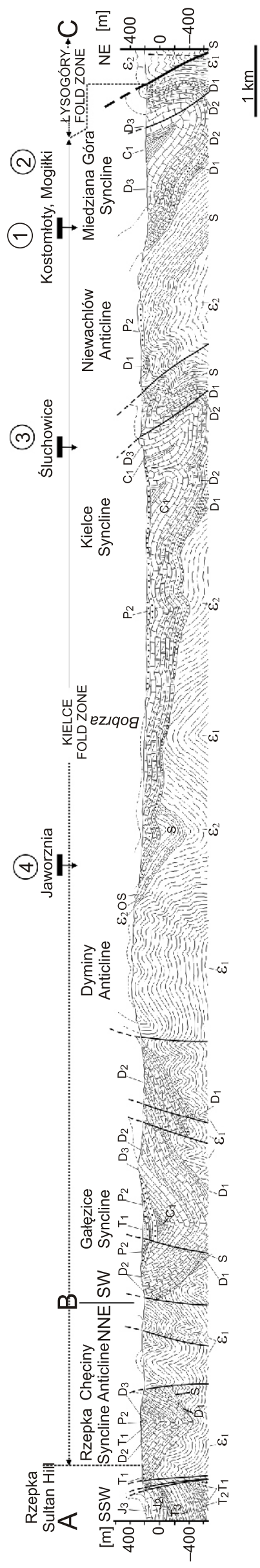

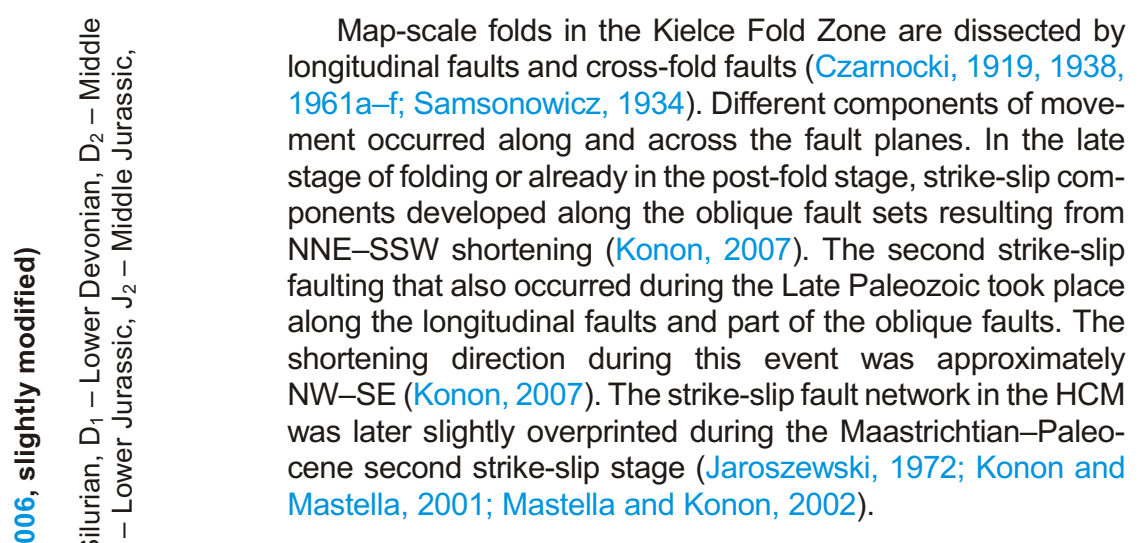

\section{LITHOSTRATIGRAPHY OF THE KIELCE FOLD ZONE}

The Paleozoic succession in the Kielce Fold Zone comprises Cambrian to Permian, mainly unmetamorphosed, siliciclastic and carbonate rocks (e.g., Czarnocki, 1919, 1938; Fig. 2). The Cambrian rocks exposed in the hinge zones of anticlines include Lower to Upper Cambrian shales alternating with thin-bedded, fine-grained sandstones, and sandstones with intercalations of conglomerate (Orłowski, 1975; Szczepanik et al., 2004a, b; Geyer et al., 2008). Above the Upper Cambrian-Ordovician unconformity a series of transgressive facies are represented by Ordovician offshore sandstones, which are gradually replaced by limestones. Silurian rocks comprise 150-300 m thick graptolitic shales passing upwards into a 300-500 m thick succession of greywackes, described as flysch-like (see Kozłowski, 2008 for review). Locally, an over $140 \mathrm{~m}$ thick shale-sandstone succession and up to $120 \mathrm{~m}$ thick conglomerate unit have been recognized in a few places near the HCF (Malec, 1993, 2001; Tomczykowa, 1993; Kozłowski, 2008). The deposits are followed by a Lower Devonian sequence about $250 \mathrm{~m}$ thick, consisting of Lochkovian-Pragian conglomerates and Emsian quartzitic sandstones with intercalations of shale (Tarnowska, 1981; Szulczewski, 1995). Middle and Upper Devonian carbonate rocks represent the Devonian carbonate platform, which attained a thickness of about $1400 \mathrm{~m}$ (Racki, 1993; Szulczewski, 1995; Szulczewski et al., 1996). The lower part of this succession (generally Eifelian and Lower Givetian) comprises dolostones, whereas above, up to the Fammenian, shales and limestones are prevalent. Above the Devonian rocks is a Carboniferous succession comprising siliceous shales with radiolarites and siderites. Their thickness is estimated from $25 \mathrm{~m}$ in the southwestern part of the Kielce Region (Szulczewski et al., 1996), through about $250 \mathrm{~m}$ farther north (Żakowa and Migaszewski, 1995), and reaches its maximum in the central parts of the region, where thicknesses exceeding $400 \mathrm{~m}$ were reported (Żakowa, 1981). The youngest folded rocks belong to the Upper Visean and are unconformably overlain by Permian rocks (e.g., Czarnocki, 1938).

\section{METHODS}

Calcite veins that occur parallel to bedding have been investigated in quarries within well-exposed Devonian carbonate and siliciclastic rocks. Some of the exposures have been exploited since the fieldwork was carried out. Samples were taken from bedding-parallel veins and host rocks. Bedding-oriented sam- 
ples were collected in order to precisely recognize kinematic indicators during petrographic investigation. Analysis of the geometry and relationships between the veins and the host rocks were based on field studies and microstructural observations on thin sections cut along the slickenlines on the vein planes. The calcite veins were studied by means of conventional optical microscopy, X-ray diffraction (XRD) and electron-probe micro-analyser (EPMA).

The mineralogical composition of the calcite veins was determined with a $D R O N-1$ diffractometer at the Institute of Geochemistry, Mineralogy and Petrology, University of Warsaw. The samples were irradiated with $\mathrm{CoK}_{\alpha}$ radiation and XRD data were collected over the range $5-70^{\circ} 2 \theta$, in the step-scan mode employing $0.04^{\circ} 2 \theta$ step-size, and counting time $4 \mathrm{~s}$ per step.

The chemical composition of the calcite was determined by EPMA using a CAMECA SX100 microprobe at the Inter-Institute Analytical Complex for Minerals and Synthetic Substances at the University of Warsaw. The analyses were performed using an accelerating voltage of $15 \mathrm{keV}$, beam current of $10 \mathrm{nA}$ and beam diameter of up to $40 \mu \mathrm{m}$. Natural and synthetic standards distributed by CAMECA and SPI Supplies were used during calibration.

\section{CHARACTERISTICS OF VEINS}

Bedding-parallel veins were examined in the map-scale folds of the Kielce Fold Zone e.g., on the southern (Jaworznia Quarry) and the northern limbs of the Kielce Syncline (Śluchowice Quarry) and on the southern limb of the Miedziana Góra Syncline (Mogiłki and Kostomłoty quarries; Figs. 1B and 3). The veins occur in variously bedded, competent and in- competent rocks: medium- and thick-bedded limestones (Jaworznia Quarry), thin- and medium-bedded limestones with interlayers of thin-bedded shales and marls (Mogiłki and Śluchowice quarries) as well as in thin-bedded limestones, shales and marls (Kostomłoty Quarry; Figs. 4-6). In most cases the veins tend to occur within thin interlayers of shales or near the boundaries between limestones/shales and marls/shales (Fig. 5B).

Bedding-parallel veins are common on the fold limbs and may be traced continuously throughout the hinge with decreasing thickness in a few exposures. They occur as sub-planar bodies between the sedimentary layers. The veins reach $1-10 \mathrm{~cm}$ in thickness and several of centimetres to tens of decimetres in length. The bedding-parallel veins are bounded by slickensides corresponding with the sense of flexural slip on bedding planes (e.g., Fig. 6B). Straight or stylolitic morphologies of the vein boundaries are common in competent thick-bedded limestones, whereas in the incompetent thin-bedded shales and marls the veins are frequently sheared (Fig. 5B).

COMPOSITION, TEXTURES, GEOMETRIC FEATURES AND INTERNAL STRUCTURE OF THE BEDDING-PARALLEL VEINS

Bedding-parallel veins consist of calcite with chemical composition close to the stoichiometric formula (Fig. 7). The sum of the trace elements $(\mathrm{MgO}, \mathrm{FeO}, \mathrm{MnO})$ does not exceed $1.5 \mathrm{wt} . \%$, and $\mathrm{FeO}$ always show the highest trace element content in all samples studied. Veins filled with fibrous calcite and all highly recrystallised veins have higher FeO contents (Fig. 7). Enrichment in $\mathrm{FeO}, \mathrm{MgO}$ and $\mathrm{MnO}$ in the calcite veins filled by fibrous calcite may also reflect a stronger contamination by tiny host rock particles. Quartz is present in the veins as an acces-

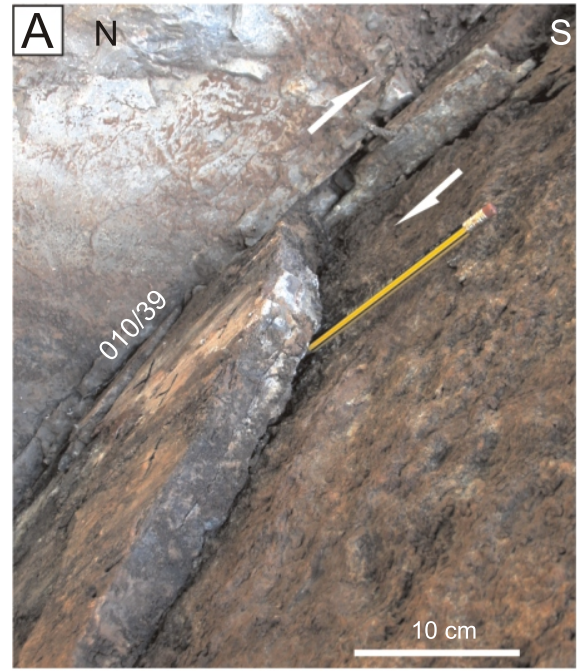

C

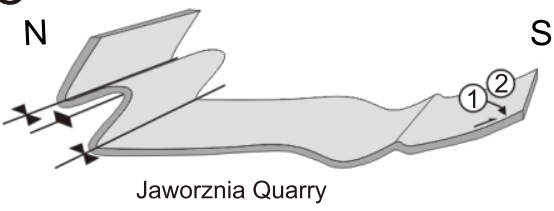

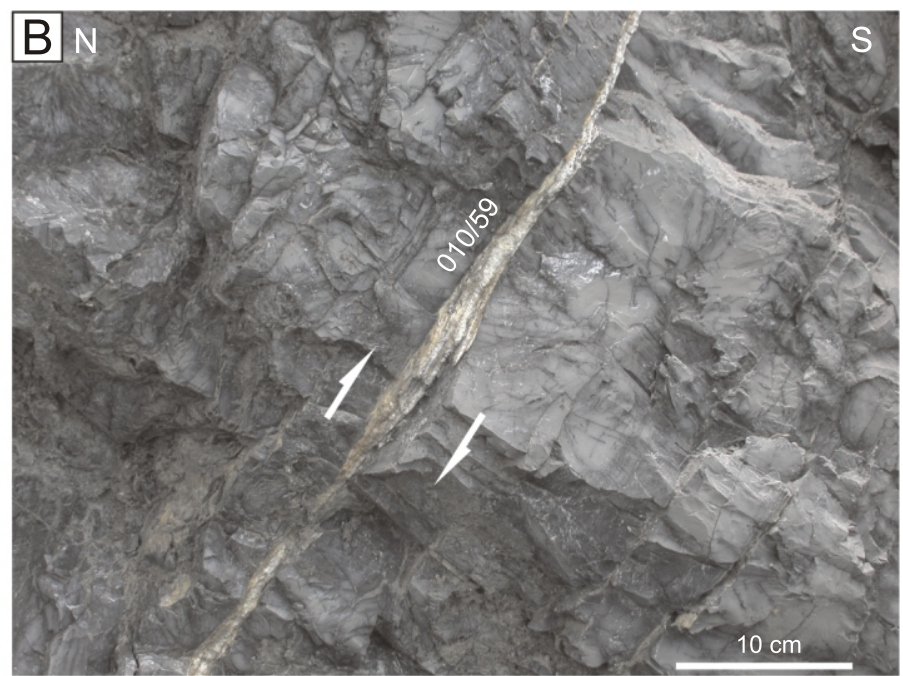

$\mathrm{D}$

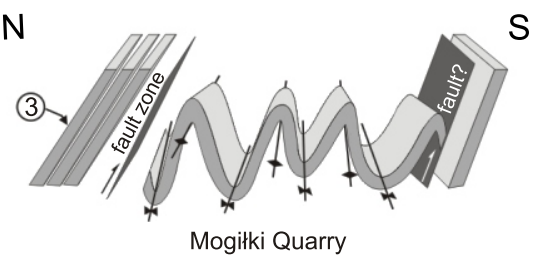

Fig. 4. Examples of bedding-parallel calcite veins

A - in thick-bedded limestones and thin-bedded shales in Jaworznia Quarry, bedding plane 010/39; B - in medium-bedded limestones and thin-bedded shales in Mogiłki Quarry, the vein shows multilayered structure, bedding plane 010/59; C, D - location of sampled bedding-parallel veins on the fold sketches; arrows show sense of slip recognized on the basis of slickensides on vein plane 


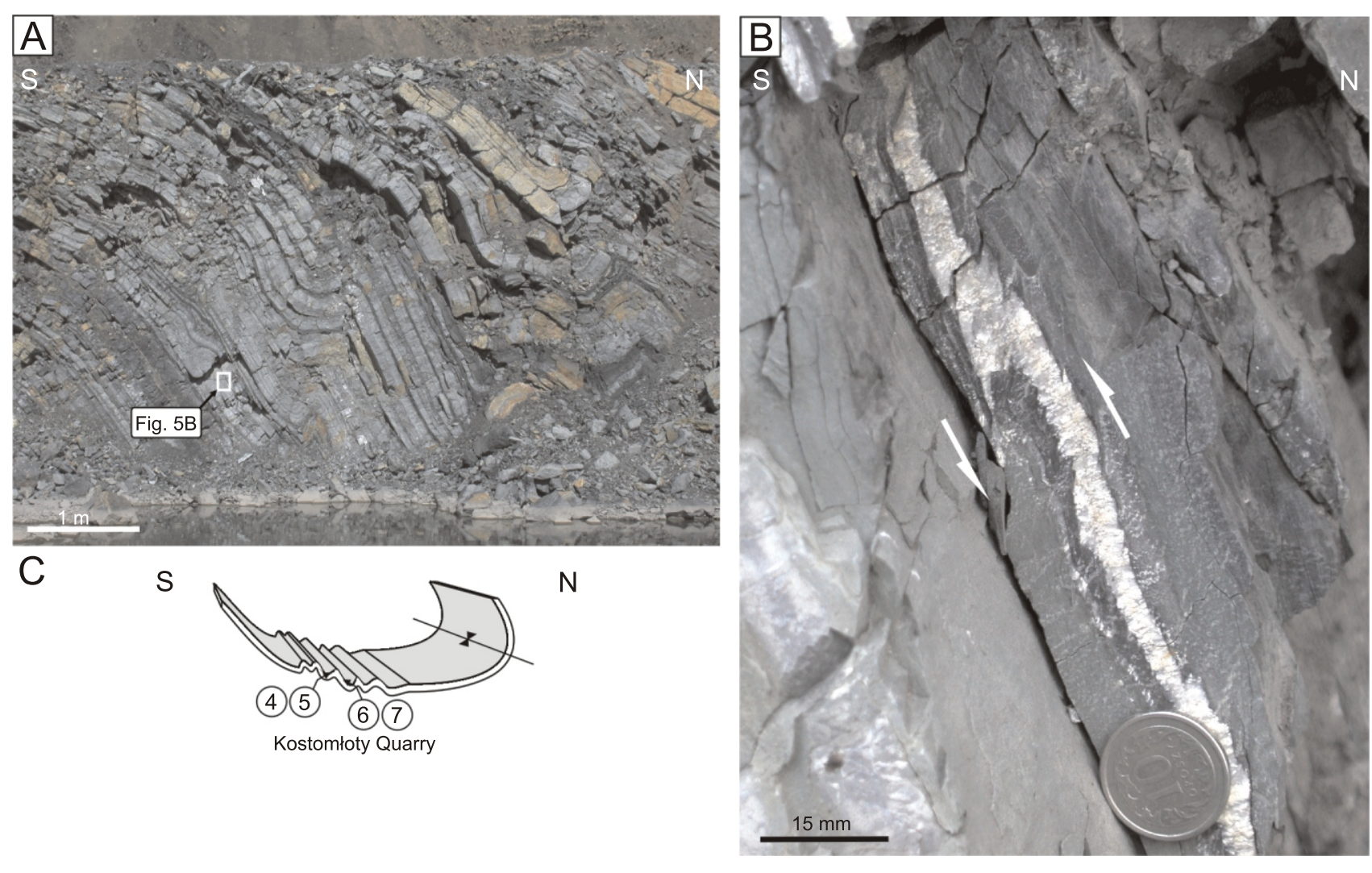

Fig. 5A - fragment of mesofold in Devonian shales and marls on the western wall of Kostomłoty Quarry; B - bedding-parallel calcite vein with marked sense of slip, bedding plane 350/50;

C - location of sampled bedding-parallel veins on the fold sketch (Konon, 2006)

Arrows show sense of slip recognized on the basis of slickenside on vein plane

sory mineral infilling minor fractures and microfaults in the calcite veins (Figs. 8E and 9C, D).

The veins occurring on limbs with dip angles of $20-30^{\circ}$ show mainly primary growth fabric, whereas in the veins occurring on limbs with a dip angle of $30-70^{\circ}$, the fabric is rebuilt or partly changed (Fig. 8). Thus, several microstructurally different domains are present within the veins.

Two main types of bedding-parallel veins with primary growth textures can be distinguished: syntaxial veins and antitaxial veins (Fig. 8A, C, E).

\section{SYNTAXIAL VEINS}

The bedding-parallel veins of this type occur in thin interlayers of shale within the thick- or medium-bedded limestones in the Jaworznia and Mogiłki quarries, respectively (Figs. 4 and 8A, C). The veins display a multilayered structure with sheets separated by host rock particles, stylolitic seams or calcite growth surfaces (Fig. $8 \mathrm{C}$ ). The veins are mainly bitaxial with readable median line, infilled with blocky or elongated calcite (Fig. 8A-D). The calcite shows deformation twinning (Fig. 8B, D). Twins are tabular or wedge-shaped, rarely tapered. Apart from twins, microfracturing is also present but less common. The vein calcite grains in limestones show epitaxial overgrowth on the host rock grains. The grain sizes range from $0.1 \mathrm{~mm}$ at the edges of the veins to $5 \mathrm{~mm}$ towards their centres. Calcite grains show perpendicular or occasionally oblique rela- tionships with the vein wall (Fig. 8A, C). In a few places, some of the grains in the vein centre show a subhedral habit.

The fabric of the calcite veins indicate that calcite was growing towards the vein centre. The composition of the veins and host rock as well as geometric features suggest syntaxial growth of calcite (Durney and Ramsay, 1973; Ramsay and Huber, 1983). Additionally the inclination of grains may suggest oblique vein growth (Petit et al., 1999). Nevertheless the presence of subeuhedral calcite as well as open holes in the central part of the veins indicate that calcite was growing into open space in some parts of the veins. Hence this fabric records the orientation of the fracture consistent with bedding and face-controlled growth of calcite.

The outer parts of the veins contain two different domains that developed due to deformation of the primary growth fabric: an irregular fabric zone (ifz) and a laminated zone (IZ; Figs. 8A, $C$ and $9 A, B)$. These domains either occur separately or the irregular fabric zones are located close to the contact of the laminated zones with primary growth textures.

The irregular fabric zones are up to $2 \mathrm{~mm}$ wide and several centimetres long. They consist of fine, irregularly shaped anhedral calcite. The crystal size exceeds $0.2 \mathrm{~mm}$ (Fig. 9A). Locally, aggregates of the calcite are randomly distributed within the primary growth texture domains in the veins.

The laminated zones are connected with irregular parts of the vein walls (Figs. 8A, C and 9B). The length of the zones ranges from a few to tens of millimetres and the width from 0.2 to $2 \mathrm{~mm}$. The elongated calcite grains are parallel or sub-parallel to the vein walls. Remnants of calcite growth fabric were 

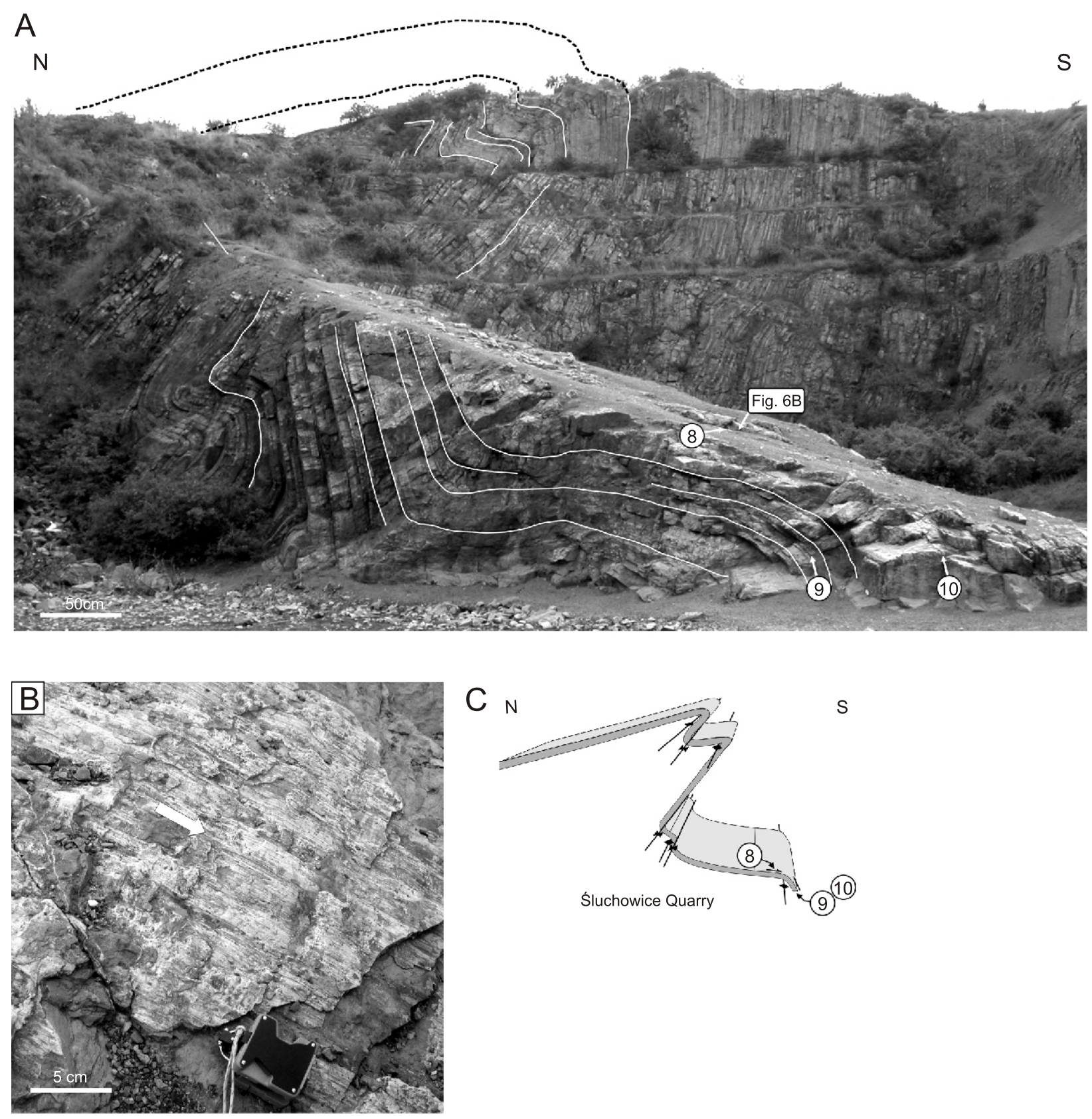

Fig. 6A - mesofolds developed in Devonian rocks in the Śluchowice Quarry with marked places of sampling; B - an example of slickenside on bedding-parallel calcite vein surface, the slickenside displays striation and congruous steps, arrow indicates the sense of movement of the missing bed, bedding plane 350/29; C - location of sampled bedding-parallel veins on the fold sketch

noted in the laminated zones (Fig. 9B). Locally, the laminated zones are subdivided by thin particles of shale and limestone further referred to as host rock inclusions. Two types of host rock inclusions are distinguished: discontinuous, sub-planar, parallel to the vein walls (I) and small inclusions inclined at high angles to the vein walls $\left(\sim 70^{\circ}\right)(\mathrm{II})$.

\section{ANTITAXIAL VEINS}

The second type of bedding-parallel vein occurs in shales and marls in the Kostomłoty Quarry and in limestones interbedded with shales in the Śluchowice Quarry (Figs. 5 and 6). The veins are bitaxial, rarely unitaxial, filled with fibrous calcite (Fig. 8E). Fibres extending from the central median line of the veins towards the vein walls in both directions exceed $6 \mathrm{~mm}$ in length and have a width of more than $0.2 \mathrm{~mm}$. They are curved, sigmoidal in shape or inclined slightly towards the hinge of the sampled fold. The inclination of fibres relative to the vein walls changes within the vein from $80^{\circ}$ in the centre to $30^{\circ}$ towards walls. Most of the straight fibres are inclined at an angle of $70-80^{\circ}$. Fibre boundaries are smooth and rarely stepped. The calcite fibres appear to be deformed and show evidence of twinning (Fig. 8F). The twins are less readable or absent at the outer parts of the veins.

The antitaxial veins contain host rock inclusions that are mostly concentrated in the vein centre underlying the median line and/or adjacent to the vein walls (Fig. 8E). Inclusions of 
Sample from Mogiłki Quarry (3)

- coarse-grained calcite vein, central part

\begin{tabular}{r|l} 
B \\
+ C
\end{tabular}

\begin{tabular}{rr|r}
+ & C & partly recrystallised calcite veins \\
* & A &
\end{tabular}

fibrous thin calcite veins

- highly recrystallised calcite veins

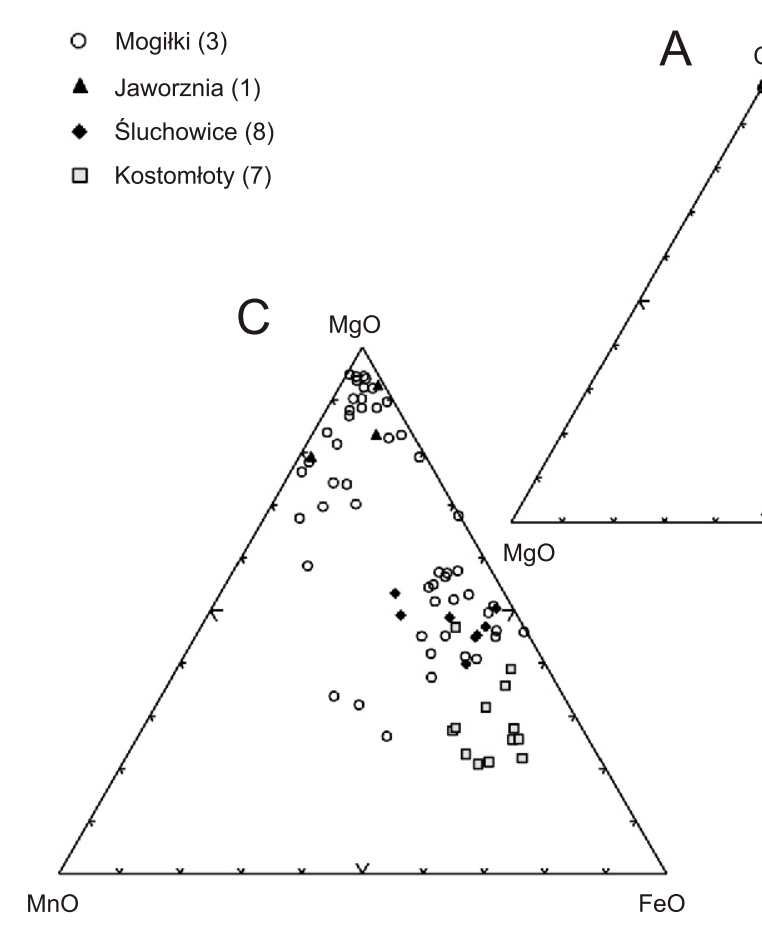

$A$

,

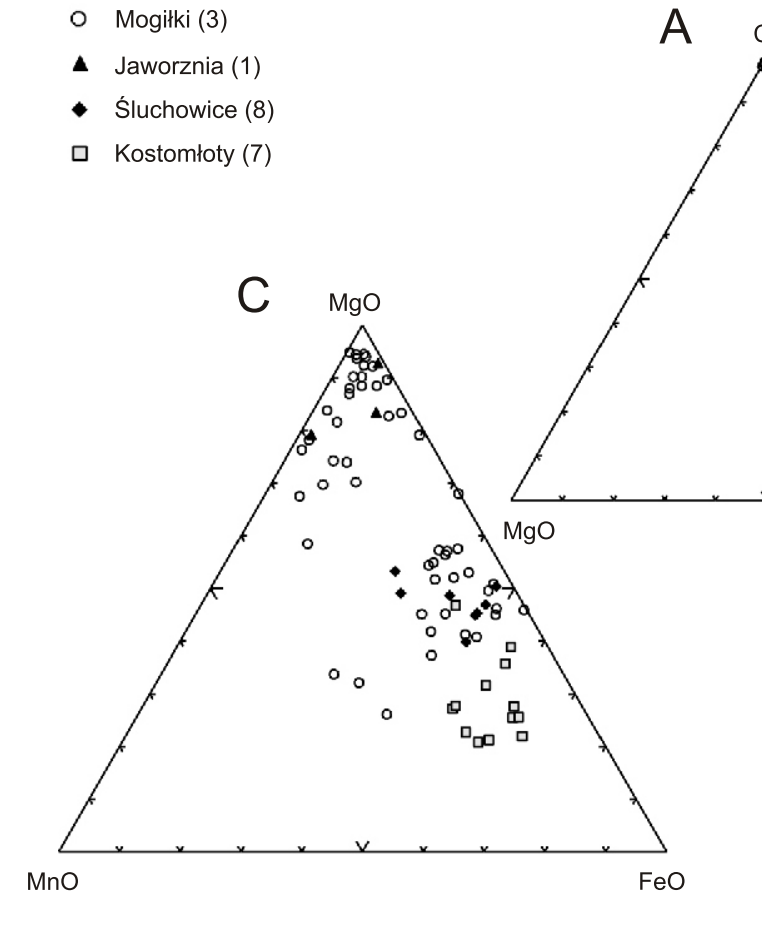

Fig. 7. Chemical composition of calcite determined by EPMA

\begin{abstract}
A - composition of all calcite samples; B - composition of calcite from different parts of the deformed calcite veins sampled at Mogiłki Quarry (sample 3); C, D - MnO-MgO-FeO and MgO*50-CaO-FeO*50 showing differences in the chemical composition of the bedding-parallel veins
\end{abstract}

both types are represented by particles of shale detached from the vein walls during vein formation. The first type of host rock inclusion, elongated or sigmoidal in shape, is isolated and rarely forms arrays. These host rock inclusions are sub-parallel or rarely slightly inclined to the vein walls (Fig. 8E). The second type of host rock inclusion usually forms arrays inclined towards the hinge of the sampled fold (Fig. 8E). This type of inclusion is incorporated into beef-like structures, similar to those first described by Hilgers and Urai (2005) and are characterized further in the text (Fig. 10E, F).

The different composition of veins and host rocks and the geometric features point to antitaxial growth of calcite according to Durney and Ramsay (1973) and Ramsay and Huber (1983). The direction of inclination and the curvature of fibres indicate syntectonic growth of calcite in the veins mutually reversed on both limbs of the sampled fold. It may also indicate oblique opening during vein growth (Cox, 1987; Petit et al., 1999; Koehn and Passchier, 2000).

Antitaxial veins contain small reverse faults (compare Rodrigues et al., 2009) that truncate the veins towards the hinge of the fold with maximum offset of the median line of $5 \mathrm{~mm}$ (Figs. 8E and 9C). Locally reverse faults are developed in the outer, upper part of the veins and continue into beef-like structures (Figs. 8E and 9D). The faulting resulted in develop- ment of shear zones filled with fibrous and/or anhedral calcite grains and aggregates of anhedral quartz grains (Fig. 9C-E). Some of the grains show undulose extinction (Fig. 9C-E), indicating deformation. The veins show subsequent growth of calcite from the tips of shear zones towards the vein walls (Figs. 8E and $9 \mathrm{C}$ ). Horsetail-like distributed thin fibres at the upper and lower fault tips are well-developed in the hanging wall (Figs. 8E and $9 \mathrm{C}$ ). The calcite grains from the foot and hanging walls adjacent to faults are differentially strained and show evidence of twinning on a level similar to that in the other parts of the vein.

Bedding-parallel calcite veins and limestones in the Śluchowice Quarry are in parts recrystallised (Fig. 9F). Aggregates of fibrous or elongated calcite are spread across the veins and limestones. A transition from undeformed limestone through stretched grains of limestone (e.g., microfossils) to aggregates of fibrous calcite has been observed (Fig. 9F).

\section{KINEMATIC INDICATORS IN THE VEINS AND HOST ROCK}

Bedding-parallel veins contain numerous microstructures considered to point to the sense of movement along the beds 

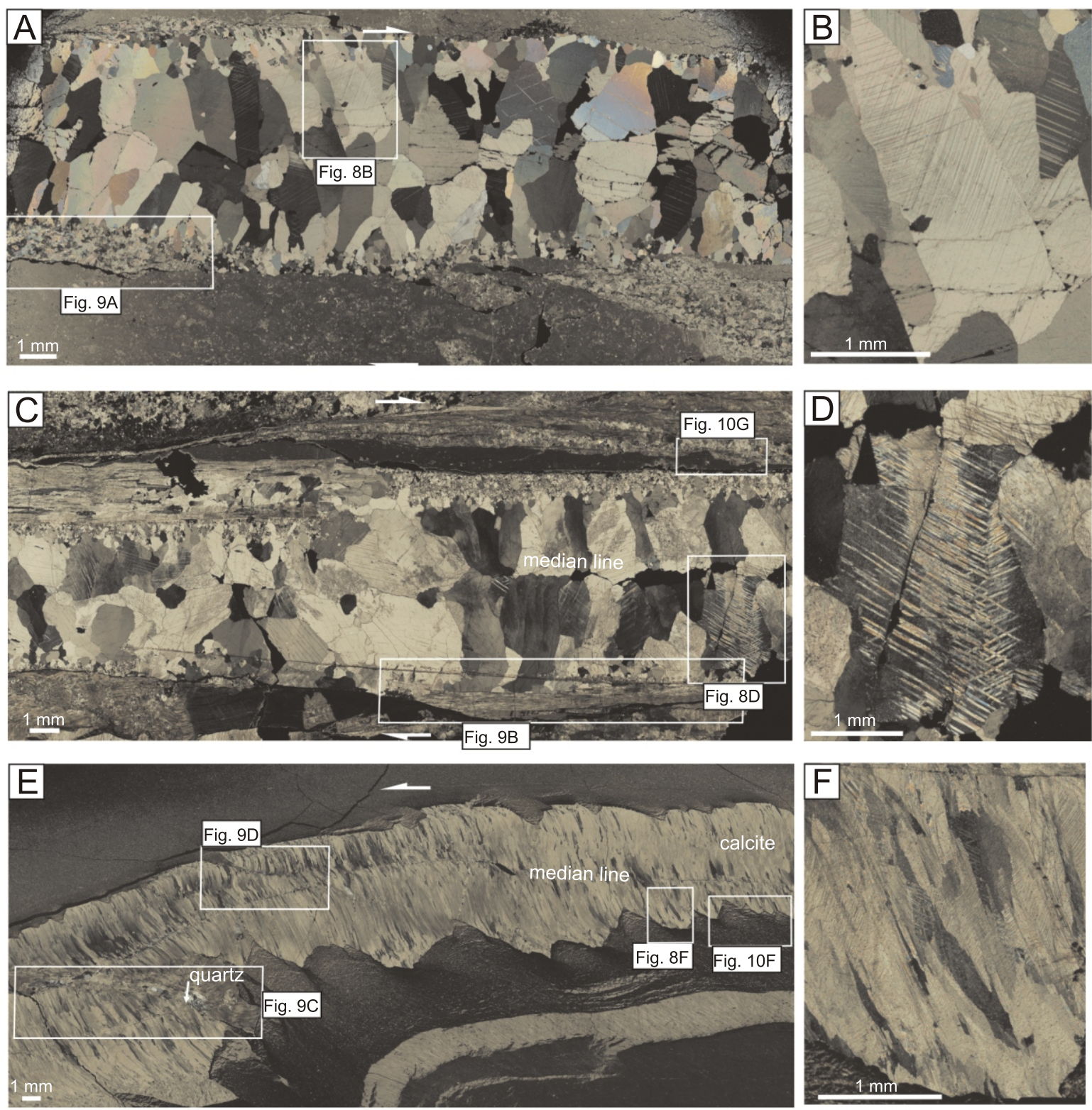

Fig. 8. Examples of textures of the bedding-parallel calcite veins

A, C - palisade texture, syntaxial vein (Jaworznia Quarry, sample 1 and Mogiłki Quarry, sample 3, respectively); B, E, F - calcite grains with twin lamellae; D - fibrous texture, antitaxial vein, central and outer zones of the vein contain host rock inclusions (Kostomłoty Quarry, sample 6); arrows show sense of slip

during the process of folding. The presence of such microstructures is conditioned by the competence and thickness of beds in the rock sequences. Five dominant microstructures may be distinguished in the bedding-parallel veins: (1) rotated blocks, (2) fibre boundary steps, (3) boudin trains, (4) beef-like structures, (5) congruous steps (Fig. 10A-G). The most common microstructures are boudin trains. The occurrence of other structures, e.g., fibre boundary steps, are related to veins formed in incompetent rocks such as marls and/or shales. Additionally fish-shaped structures have been distinguished in the shale host rock close to the calcite veins (Fig. 10H). The kinematic indicators observed on limbs of sampled folds point to simple shear consistent with flexural slip in the sense of movement.

\section{ROTATED BLOCKS}

Rotated blocks occur in the outer part of the antitaxial veins in elongated and fibrous aggregates of calcite as microfault-bounded block domains (Fig. 10A). The blocks are up to $1 \mathrm{~mm}$ across and are rotated by up to $10^{\circ}$ in domino style towards the hinge of the fold.

FIBRE BOUNDARY STEPS

The calcite fibres in the antitaxial veins show stepped boundaries (Fig. 10B). The steps along fibre-fibre contacts exceed $0.01 \mathrm{~mm}$ in size and continue in the calcite grains as discrete sys- 

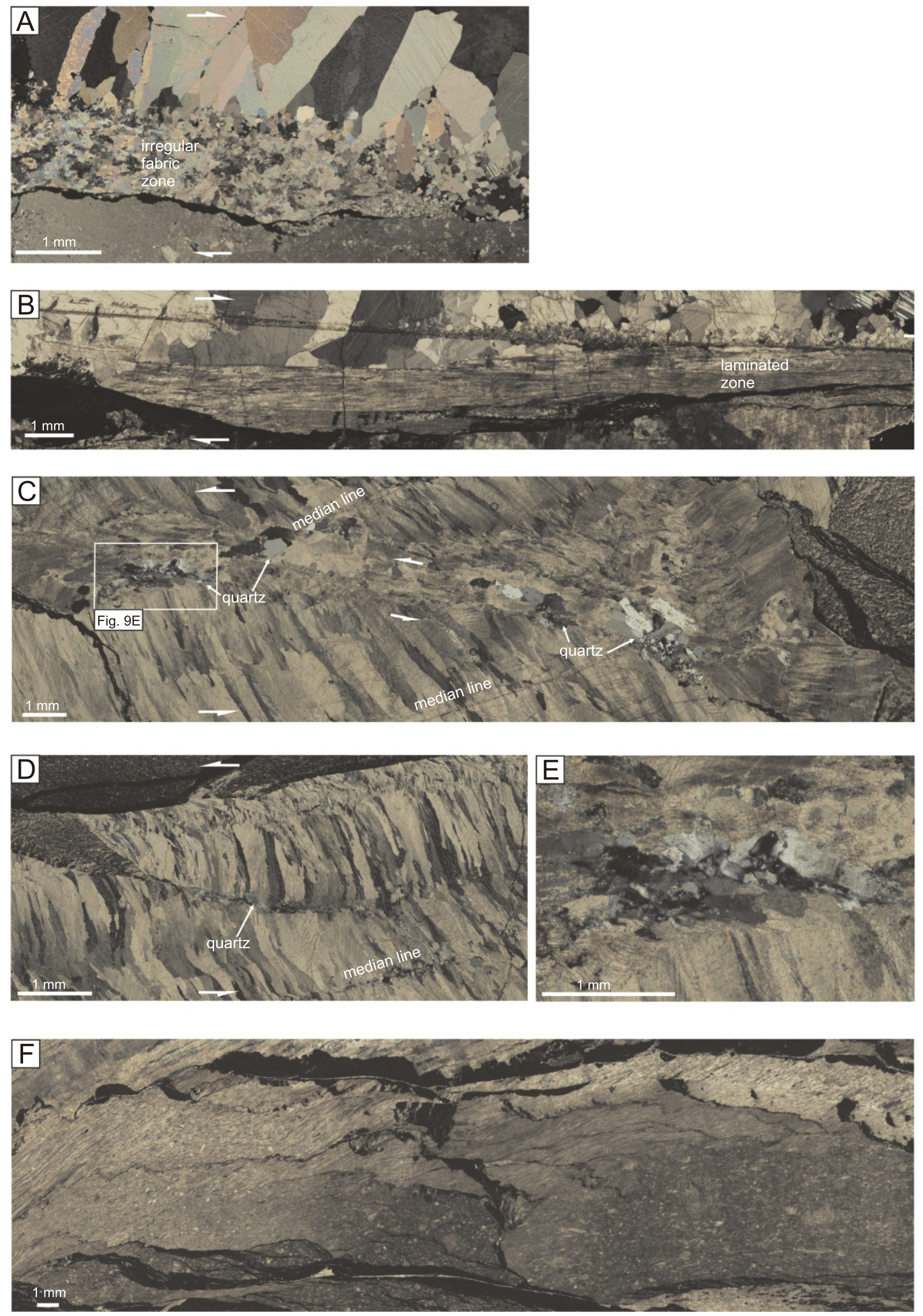

Fig. 9. Evidence of progressive deformation of veins in form of a secondary fabric

A - irregular fabric zone with irregularly shaped calcite, partly with lobate boundaries (Jaworznia Quarry, sample 1); B - laminated zone with elongated and fibrous calcite (Mogiłki Quarry, sample 3); C, D - shear zones resulting from reverse faulting of the vein during buckle folding (Kostomłoty Quarry, sample 6); E - quartz grains with undulose extinction within shear zone (Kostomłoty Quarry, sample 6); $\mathbf{F}$ - transition from undeformed limestone (bottom), through stretched bioclasts of limestone (centre), to aggregates of fibrous calcite (top) (Śluchowice Quarry, sample 8); arrows show sense of slip 


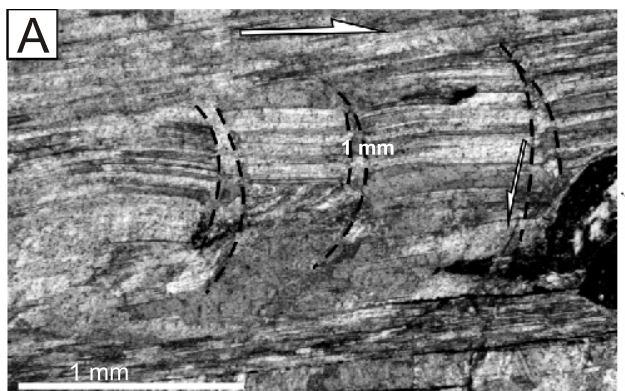

rotated blocks
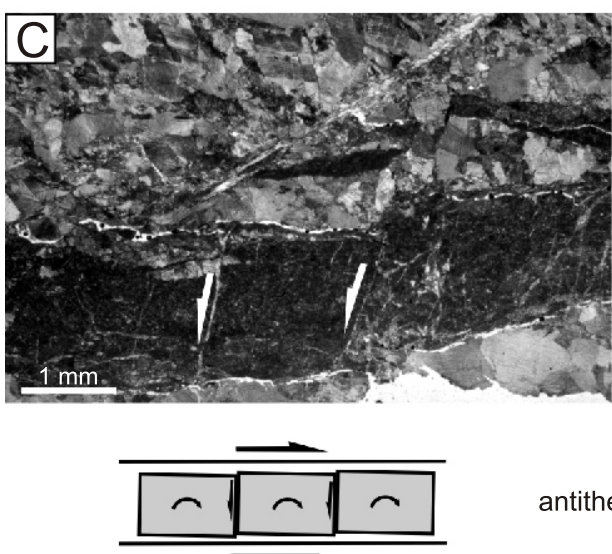

antithetic-slip boudinage
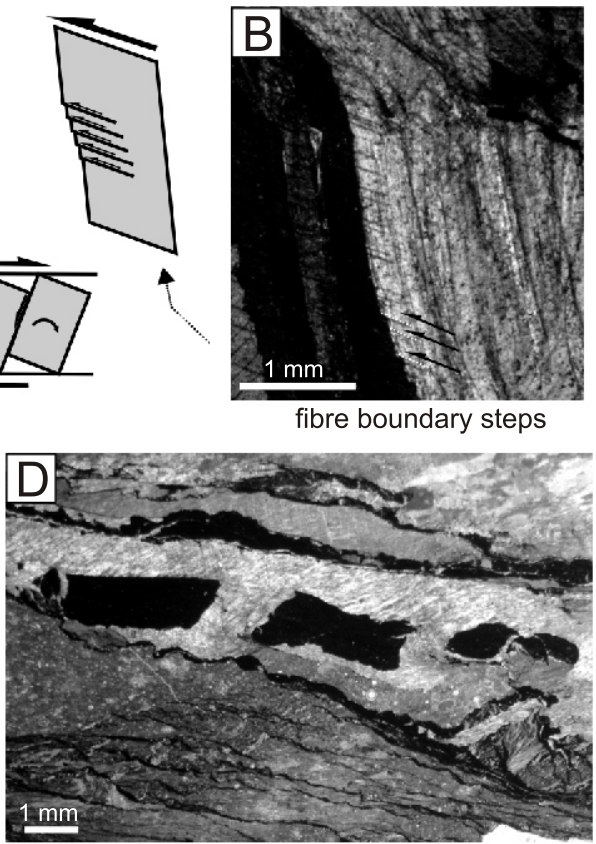

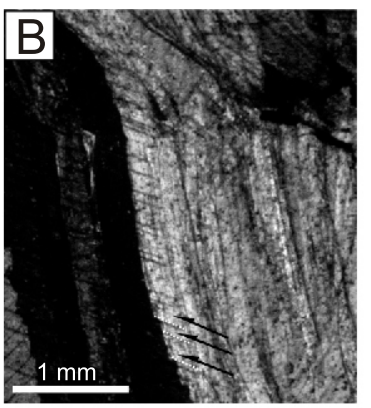

fibre boundary steps
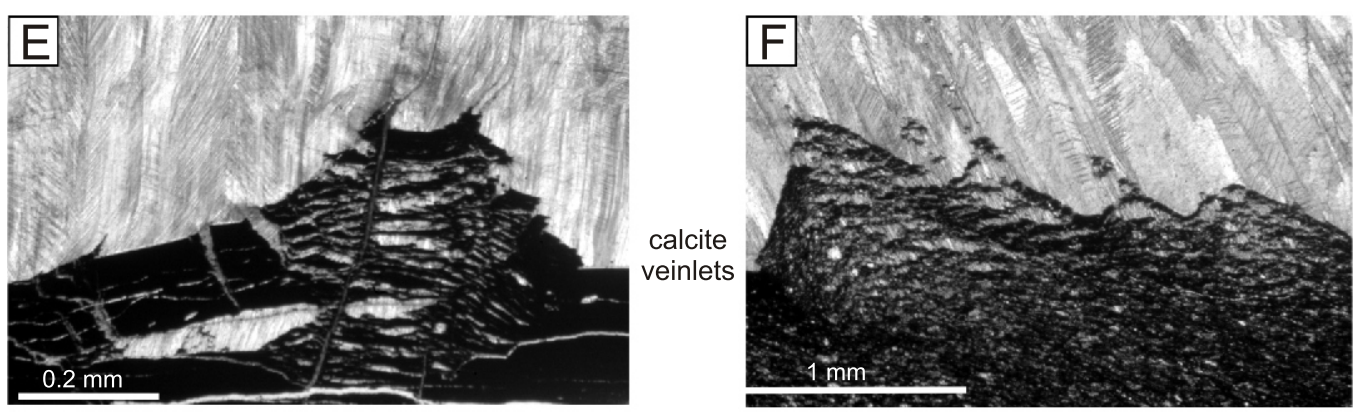

beef-like structures

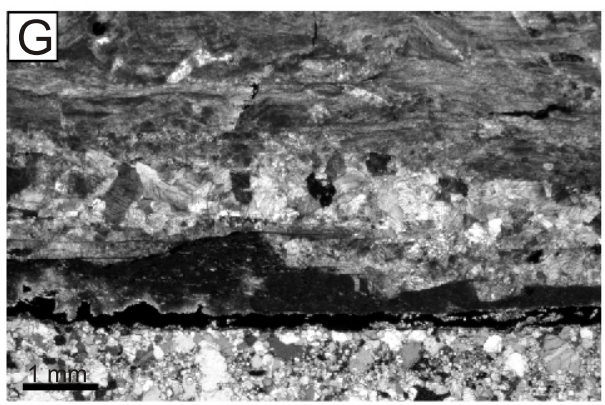

congruous steps

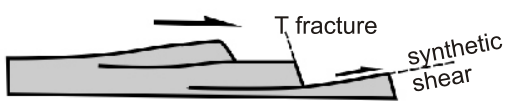

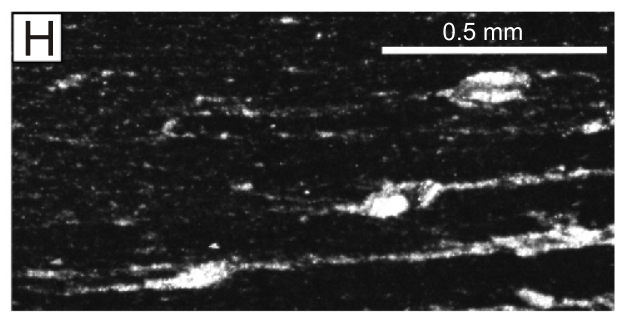

fish-shaped structures

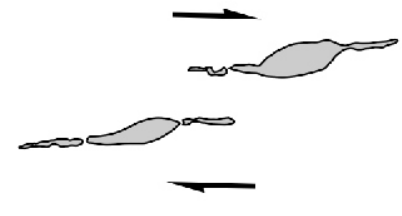

Fig. 10. Examples of kinematic indicators in the bedding-parallel calcite veins and host rock

A - small blocks in the calcite vein rotated in domino style (Konon, 2006); B - systematic stepping of a fibre boundary (Konon, 2006; veins sampled in Kostomłoty Quarry, samples 4 and 7, respectively); C, D - rhomboidal and sigmoidal boudins with forward vergence, inter-boudin surfaces show occurrence of the dip-slip component with a normal sense (Jaworznia Quarry, sample 2, Sluchowice Quarry, sample 8, respectively); E, F - examples of beef-like structures with numerous veinlets separated by elongated particles of shale (Kostomłoty Quarry, samples 5 and 6, respectively); $\mathbf{G}$ - asymmetrical repeated steps with dihedral morphology (Mogiłki Quarry, sample 3 ); $\mathbf{H}$ - fish-shaped structures with stepping-up geometry (Kostomłoty Quarry, sample 5); arrows show sense of slip 
tematic shears. The shear length ranges between $0.02-0.08 \mathrm{~mm}$. These shears are sub-parallel to the vein walls. Systematic stepping of fibre-fibre boundaries is consistent with the sense of movement interpreted from calcite growth (Konon, 2006). This corresponds to the flexural slip direction mutually reversed in both limbs of the sampled fold. These observations suggests that fibre boundary steps developed during syntectonic growth of calcite grains following an opening trajectory that was oblique to the vein walls and median line. We interpret that the shears synthetic with respect to the flexural slip could have been formed simultaneously with fibre boundary steps.

\section{BOUDIN TRAINS}

Boudin trains occur in thin-bedded limestones and shales (Fig. 10C, D). The boudin shape is predominantly rhomboidal (limestones, shales), sporadically lenticular or sigmoidal (shales). In some cases, dilation occurs across the inter-boudin surface forming inter-boudin zones. The inter-boudin gaps are filled with blocky or fibrous calcite. Relative displacement along the inter-boudin surface between the individual boudins in the trains ranges from 0.1 to $0.2 \mathrm{~mm}$. The vergence defined by the inclination of the inter-boudin surfaces is forward-vergent. Angles between inter-boudin surfaces and boudin exteriors range from 55 to $65^{\circ}$. The aspect ratio of the boudins (boudin length to boudin width) varies from 1 in limestones to 3 in shales.

The orientation of the boudin trains is parallel to the main foliation in the rock matrix. Boudins show little or no evidence of internal deformation. Additionally boudin rotation is common and the rotation angle exceeds $5^{\circ}$. The sense of rotation is consistent with the flexural slip direction. Kinematic characteristics (sense of slip direction on the surface separating the boudins) and arrangement of the boudins allows us to classify them in the kinematic group of antithetic-slip boudinage of domino type (Etchecopar, 1977; Hanmer and Passchier, 1991; Swanson, 1992; Goscombe and Passchier, 2003; Goscombe et al., 2004).

\section{BEEF-LIKE STRUCTURES}

These structures are common within the antitaxial clacite veins in the study area (Fig. 10E, F). Beef-like structures (after Hilgers and Urai, 2005) occur in thin interlayers of shale and marl within limestones or at their boundaries. They create a saw-like morphology of the vein walls (Fig. 8E). Beef-like structures consist of numerous sub-parallel calcite veinlets, separated by elongated particles of shales, forming stacks (Fig. 10E, F). The veinlets are sub-parallel to the vein walls and are wavy or lenticular in shape and infilled with fibrous calcite. The fibres grow in the same direction as fibres in the bedding-parallel veins. The stacks of veinlets and host rock particles show an asymmetrical geometry with vergence towards the hinge on both limbs of the sampled mesofold (Fig. 10E, F). The vergence is consistent with the flexural slip in the sense of movement. The veinlets continue within the vein in arrays of host rock inclusions, which are hosted in the calcite crystals or along the crystal boundaries. The distribution of the host rock inclusions and the asymmetry of the structures reflect primary foliation - cleavage in the shales. There is no evidence for shearing along cleavage in the floor bed of the host rock.

\section{CONGRUOUS STEPS}

Steps tend to occur in incompetent rocks, mainly in shales. Steps represent asymmetrical repeated features with a dihedral morphology. Bedding-parallel veins occurring in the shales show congruous steps (Fig. 10G). Threads of steps lie at the angle of 0 to $10^{\circ}$ with risers at $50-60^{\circ}$ to the bedding plane. Such an asymmetrical structure was probably formed by the intersection of synthetic shears and T fractures corresponding to threads and risers respectively. The shears tend to parallelism with the bedding plane at their tips. The orientation of congruous steps in relation to the slickenlines on vein planes suggest that shears and fractures were produced during displacement of vein walls resulting from simple shearing that corresponds with flexural slip, similar to those described from brittle fault zones by Norris and Barron (1969) and Petit (1987).

\section{FISH-SHAPED STRUCTURES}

Fish-shaped structures filled with calcite occur in abundance within thin-bedded black shales adjacent to antitaxial veins from Kostomłoty Quarry (Fig. 10H). The fish represent asymmetrical structures of lens shape with angular tips and so far they have been known from mylonitic rocks (Passchier and Simpson, 1986; Hanmer, 1990; Passchier, 1994). The fish-shaped structures investigated show stepping-up towards the hinge of the sampled mesofold (Fig. 10H). The tips of the structures continue into thin trails of small calcite grains extending on both sides of the isolated fish into the matrix parallel to each other and slightly oblique (angle of about $5^{\circ}$ ) to the main foliation of the enclosing matrix. The geometry and orientation of the fish-shaped structures are comparable to mica fish classified to the type of group 1 sensu Grotenhuis et al. (2003), thus analogously we propose the same kinematic interpretation of the structures studied. The presence of the fish-shaped structures indicates a reduction of cohesion within the matrix and then between fish and matrix (e.g., Kenkmann, 2000) during their formation that probably resulted from horizontal shortening. The process may have been accompanied by pressure solution mass transfer resulting in a lens-shaped geometry of the structures (Grotenhuis et al., 2003). Thus calcite fish-shaped structures can be interpreted as a result of solution and precipitation processes (compare with quartz fish of Bestmann et al., 2000,2004 ) combined with flexural slip localized along bedding planes.

\section{DISCUSSION AND CONCLUSIONS}

In the Kielce Fold Zone of the HCM Fold Belt, bedding-parallel veins occur on the map-scale and mesoscopic fold limbs, and occasionally in the hinge zones. Kinematic indicators within the veins on the fold limbs such as rotated blocks, fibre boundary steps, boudin trains, beef-like structures, congruous steps and additionally fish-shaped structures within host rock indicate a sense of movement resulting from simple shear that is consistent with flexural slip on the tilted limbs. Hence we interpret that the structures could have been formed during main stage of buckle folding, a mechanism that is typical for the anticlines and synclines investigated (Figs. 3-6, 8 and 10; Konon, 2006).

The tendency of the veins to occur near the boundaries between rocks of different lithology e.g., limestones/shales, shales/marls or within the shales may be explained by contrasting mechanical properties of the different layers. The main detachment horizons developed along thin shale or marl layers favouring flexural slip and formation of bedding-parallel veins (cf. Tanner, 1989; Noten and Sintubin, 2011). Rare continuity of veins across fold hinges suggests that the formation of the veins started in the initial stage of subhorizontal shortening (stage I/II, 


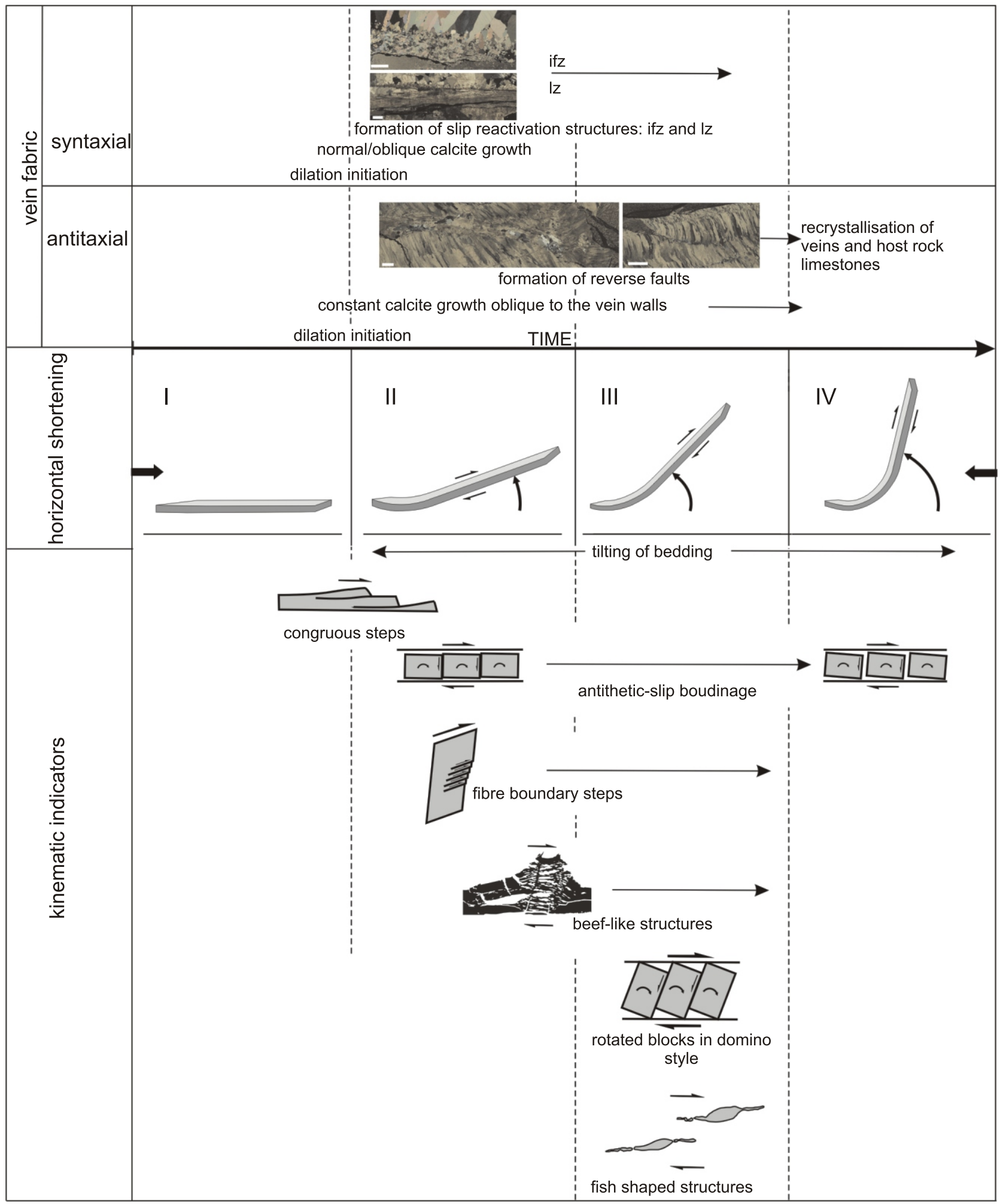

Fig. 11. Proposed model of bedding-parallel vein formation

Scale bar $-1 \mathrm{~mm}$ 
Fig. 11). Likewise the presence of syntaxial veins within thick-bedded carbonate rocks confirms the dilation of rocks at this stage. Subsequently, activation of flexural slip along the vein walls resulted in the secondary fabric development (stages II-III, Fig. 11). The occurrence of antitaxial veins with fibrous fabric tracking the opening trajectory of the veins within the thin-bedded carbonates with interlayers of shales and marls point to operating of dilation and simple shear along bedding planes at the same time during folding (stages I-IV, Fig. 11). Hence antitaxial veins can be interpreted as synfolding veins.

Bedding-parallel veins display several microstructural features giving hints of the mechanism of vein formation. All of the veins show evidence of opening (stages I/II, Fig. 11) such as detached and displaced host rock inclusions (Ramsay, 1980; Cox and Etheridge, 1983; Lee and Wiltschko, 2000; Hilgers and Sindern, 2005), which are concentrated mostly in the centre of the veins or adjacent to the vein walls (Figs. 8-10). The position of these host rock pieces indicate that cohesion was lost along the bedding planes due to subhorizontal shortening and progressive incorporation of host rock particles into the vein fabric.

Syntaxial veins display blocky or elongated grains, which rarely have a subhedral habit, increase in grain size towards the vein centre and show an absence of stepped grain boundaries. The fabric of these veins indicate that the opening direction was normal to the vein wall rather than slightly oblique (Fig. 8C) and that vein growth involved open space filling (Fig. 8A). The latter observation suggests that the opening of some parts of the veins was faster than the growth of calcite so that the veins could not be filled completely. We interpret that the typical syntaxial veins with median lines (Fig. 8C) record normal syntectonic growth of calcite, whereas the veins with subhedral grains of calcite (Fig. 8A) record the orientation of the bedding plane and face-controlled calcite growth mechanism (cf. Hilgers and Urai, 2002a). The presence of a median line and locally subhedral calcite grains as well as open holes in the same vein suggest the heterogeneous growth of calcite within the vein.

Antitaxial veins display stepped fibre boundaries that are considered as indicators of the crack-seal mechanism (Ramsay, 1980; Cox, 1987; Passchier and Trouw, 1996). However, smooth fibre boundaries are also common and the veins show little or no evidence of inclusion bands documenting repeated crack-seal increments. Additionally recent studies have shown that host rock inclusions incorporated into beef-like structures may have been formed during constant growth of calcite across the antitaxial vein (Hilgers and Urai, 2005).

Antitaxial veins imply an oblique opening relative to the vein walls and a continuous growth of calcite at the vein/host rock contact (stages from I/II to III, Fig. 11) similar to the results of laboratory simulation of Bons and Jessel (1997) and Means and Li (2001) and on conditions proposed by Hilgers and Urai (2002b) and Hilgers and Sindern (2005). The curvature and inclination of calcite fibres as well as the fibre boundary steps record simple shear consistent with flexural slip path during folding. The lack of fibre twinning or poorly defined twinning in the outer parts of the antitaxial veins in comparison to the inner parts implies diminishing of strain rate towards the vein walls (e.g., Hilgers and Urai, 2002b). The interpretation confirms that synfolding growth of calcite with the youngest grains recording a highly obligue vein opening which resulted from flexural slip. The evidence of calcite growth from the tips of reverse faults towards the vein walls implies that subsequent calcite precipitation during and after vein faulting resulted from constant subhorizontal shortening (compare Rodrigues et al., 2009).

The bedding-parallel veins were frequently deformed during all stages of the folding process (Figs. 8, 9 and 11). We conclude that vein fabric as well as kinematic indicators record evidence of the gradual formation of the vein and the progression of fabric development, which is mostly consistent with an increasing dip angle of the fold limbs and their gradual deformation (stages I-IV, Fig. 11). The presence of calcite twinning is an ubiquitous indicator of initial deformation. Veins occurring in steeper limbs show secondary fabric development in the form of slip-reactivated features (stage II-III) and are partly recrystallised (stage IV; Figs. 8, 9 and 11).

We conclude that the formation of syntaxial veins is related to an initial stage of horizontal shortening whereas the formation of fibrous antitaxial veins and kinematic indicators as well as a secondary fabric within syntaxial veins are related to buckling in the study area. The homogeneous chemical composition of the calcite in the veins points to stable conditions of calcite crystallisation. The structures observed record the loss of cohesion along bedding planes due to constant horizontal shortening probably in a closed geochemical system. We conclude that the vein fabric and the kinematic indicators record syntectonic gradual deformation of the rocks and point to their development from horizontal to buckled bedding during the Late Paleozoic buckle folding in the HCM Fold Belt.

Acknowledgements. This research was supported by the Institute of Geology, University of Warsaw. We thank M. Sintubin and D. Koehn for their constructive and useful comments. We are grateful to A. Żylińska and R. Macdonald for linguistic improvement of the manuscript.

\section{REFERENCES}

Belka Z., Valverde-Vaquero P., Dörr W., Ahrendt H., Wemmer K. Franke W. (2002) Accretion of first Gondwana-derived terranes at the margin of Baltica. Geological Society Special Publications, 201: 19-36.

Berthelsen A. (1993) Where different geological philosophies meet: the Trans-European Suture Zone. Publications of the Institute of Geophysics, 255: 19-31.

Bestmann M., Kunze K., Matthews A. (2000) Evolution of a calcite marble shear zone complex on Thassos Island, Greece: microstructural and textural fabrics and their kinematic significance. Journal of Structural Geology, 22: 1789-1807.

Bestmann M., Prior D.J., Veltkamp K.T.A. (2004) Development of single crystal sigma-shaped quartz porphyroclasts by dissolu- tion-precipitation creep in a calcite marble shear zone. Journal of Structural Geology, 26: 869-883.

Bons P.D., Jessell M.W. (1997) Experimental simulation of the formation of fibrous veins by localised dissolution-precipitation creep. Mineralogical Magazine, 61: 53-63.

Bons P.D., Montenari M. (2005) The formation of antitaxial calcite veins with well-developed fibres, Oppaminda Creek, South Australia. Journal of Structural Geology, 27: 231-248.

Cobbold P.R., Rodrigues N. (2007) Seepage forces, important factors in the formation of horizontal hydraulic fractures and bedding-parallel fibrous veins ("beef" and "cone-in-cone"). Geofluids, 7: 313-322. 
Cobbold P.R., Zanella A., Rodrigues N., Loseth H. (2013) Bedding-parallel fibrous veins (beef and cone-in-cone): worldwide occurrence and possible significance in terms of fluid overpressure, hydrocarbon generation and mineralization. Marine and Petroleum Geology, 43: 1-20.

Cosgrove J.W. (1993) The interplay between fluids, folds and thrusts during the deformation of a sedimentary succession. Journal of Structural Geology, 15: 491-500.

Cox S.F. (1987) Antitaxial crack-seal vein microstructures and their relationship to displacement paths. Journal of Structural Geology, 9: 779-788.

Cox S.F., Etheridge M.A. (1983) Crack-seal fibre growth mechanism and their significance in the development of oriented layer silicate microstructures. Tectonophysics, 92: 147-170.

Czarnocki J. (1919) Stratygrafja i tektonika Gór Świętokrzyskich Prace Towarzystwa Naukowego Warszawskiego, 28: 1-172.

Czarnocki J. (1938) Carte géologique générale de la Pologne, scale 1:100 000, feuille 4, Kielce, Edition du Service Géologique de Pologne.

Czarnocki J. (1950) Geology of the Łysa Góra region (Święty Krzyż Mountains) (in Polish with English summary). Prace Państwowego Instytutu Geologicznego, IVa, 3-400.

Czarnocki J. (1956) Mineral raw material in Święty Krzyż Mountains (in Polish with English summary). Prace Instytutu Geologicznego, 12a: 5-108

Czarnocki J. (1957a) Tectonics of the Święty Krzyż Mountains. Stratigraphy and tectonics of the Świety Krzyż Mountains (in Polish with English summary). Prace Instytutu Geologicznego, 18: 11-133

Czarnocki J. (1957b) Tectonics of the Święty Krzyż Mountains. Geology of the Łysogóry Region (in Polish with English summary). Prace Instytutu Geologicznego, 18: 11-138.

Czarnocki J. (1961a) Materiały do przeglądowej mapy geologiczne Polski w skali 1:100 000. Region Świętokrzyski. Arkusz Kielce. Wyd. B zaktualizowane. Wyd. Geol., Warszawa.

Czarnocki J. (1961b) Materiały do przeglądowej mapy geologiczne Polski w skali 1:100 000. Region Świętokrzyski. Arkusz Bodzentyn. Wyd. B zaktualizowane. Wyd. Geol., Warszawa.

Czarnocki J. (1961c) Materiały do przeglądowej mapy geologicznej Polski w skali 1:100 000. Region Świętokrzyski. Arkusz Opatów. Wyd. B zaktualizowane. Wyd. Geol., Warszawa.

Czarnocki J. (1961d) Materiały do przeglądowej mapy geologiczne Polski w skali 1:100 000. Region Świętokrzyski. Arkusz Pińczów. Wyd. B zaktualizowane. Wyd. Geol., Warszawa.

Czarnocki J. (1961e) Materiały do przeglądowej mapy geologicznej Polski w skali 1:100 000. Region Świętokrzyski. Arkusz Staszów. Wyd. B zaktualizowane. Wyd. Geol., Warszawa.

Czarnocki J. (1961f) Materiały do przeglądowej mapy geologicznej Polski w skali 1:100 000. Region Świętokrzyski. Arkusz Sandomierz. Wyd. B zaktualizowane. Wyd. Geol., Warszawa.

Dadlez R., Kowalczewski Z., Znosko J. (1994) Some key problems of the pre-Permian tectonics of Poland. Geological Quarterly, 38 (2): 169-190.

Durnay D.W., Ramsay J.G. (1973) Incremental strains measured by syntectonic crystal growths. In: Gravity and Tectonics (eds. K.A. Jong de and K. Scholten): 67-96. John Wiley and Sons, New York

Etcheopar A. (1977) A plane kinematic model of progressive deformation in a polycrystalline aggregate. Tectonophysics, 39: 121-139.

Filonowicz P. (1967) Mapa Geologiczna Polski w skali 1:50 000. Arkusz Morawica. Wyd. Geol., Warszawa.

Filonowicz P. (1968) Objaśnienia Mapy geologicznej Polski w skali 1:50 000, arkusz Morawica. Wyd. Geol., Warszawa.

Filonowicz P. (1973) Mapa Geologiczna Polski w skali 1:50 000. Arkusz Kielce. Wyd. Geol., Warszawa.

Fowler T.J. (1996) Flexural-slip generated bedding-parallel veins from central Victoria, Australia. Journal of Structural Geology, 18: 1399-1415.

Goscombe B.D., Passchier C.W. (2003) Asymmetric boudins as shear sense indicators - an assessment from field data. Journa of Structural Geology, 25: 575-589
Goscombe B.D., Passchier C.W., Hand M. (2004) Boudinage classification: end-member boudin types and modified boudin structures. Journal of Structural Geology, 26: 739-763.

Geyer G., Elicki O., Fatka O., Żylińska A. (2008) Cambrian. In: The Geology of Central Europe, 1: Precambrian and Palaeozoic (ed. T. McCann): 155-202.

Grotenhuis S.M., ten, Trouw R.A.J., Passchier C.W. (2003) Evolution of mica fish in mylonitic rocks. Tectonophysics, 372: 1-21.

Hakenberg M. (1973) Mapa Geologiczna Polski w skali 1:50 000 Arkusz Chęciny. Wyd. Geol., Warszawa.

Hakenberg M., Kutek J., Matyja B.A., Mizerski W., Rutkowski J., Stupnicka E., Świdrowska J., Trammer J. (1976) Stratygrafia, wykształcenie geologiczne i tektonika mezozoiku południowo-zachodniego obrzeżenia Gór Świętokrzyskich. In: Przewodnik 48 Zjazdu PTG, Starachowice (ed. W. Pożaryski): 186-202.

Hanmer S. (1990) Natural rotated inclusions in nonideal shear Tectonophysics, 176: 245-255.

Hanmer S., Passchier C.W. (1991) Shear-sense indicators: a review. Geological Survey Canada Papers, 90-17.

Hilgers C., Sindern S. (2005) Textural and isotopic evidence on the fluid source and transport mechanism of antitaxial fibrous microstructures from the Alps and the Appalachians. Geofluids, 5: $1-12$

Hilgers C., Urai J.L. (2002a) Experimental study of syntaxial vein growth during lateral fluid flow in transmitted light: first results. Journal of Structural Geology, 24: 1029-1043.

Hilgers C., Urai J. (2002b) Microstructural observations on natural syntectonic fibrous veins: implications for the growth process. Tectonophysics, 352: 257-274.

Hilgers C., Urai J. (2005) On the arrangement of solid inclusions in fibrous veins and the role of the crack - seal mechanism. Journal of Structural Geology, 27: 481-494.

Hilgers C., Kirschner D., Breton J., Urai J. (2006) Fracture sealing and fluid overpressures on limestones of the Jabal Akhdar dome, Oman Mountains. Geofluids, 6: 168-184.

Janik T., Grad M., Guterch A. (2009) Seismic structure of the lithosphere between the East European Craton and the Carpathians from the net of CELEBRATION 2000 profiles in SE Poland. Geological Quarterly, 53 (1): 141-158.

Jaroszewski W. (1972) Mesoscopic structural criteria of tectonics of non-orogenic areas: an example from the north-eastern Mesozoic margin of the Świętokrzyskie Mountains (in Polish with English summary). Studia Geologica Polonica, 37

Jaworowski K. (2002) Geotectonic significance of Carboniferous deposits NW of the Holy Cross Mts. (central Poland). Geological Quarterly, 46 (3): 267-280.

Jessell M.W., Willman C.E., Gray D.R. (1994) Bedding parallel veins and their relationship to folding. Journal of Structural Geology, 16: 753-767

Kenis I., Muchez P.H., Sintubin M., Mansy J.L., Lacquement F (2000) The use of a combined structural, stable isotope ad fluid inclusion study to constrain the kinematic history at the northern Variscan front zone (Bettrechies, northern France). Journal of Structural Geology, 22: 589-602.

Kenkmann T. (2000) Process controlling the shrinkage of porphyroclasts in gabbroic shear zones. Journal of Structura Geology, 22: 471-487.

Koehn D., Passchier C.W. (2000) Shear sense indicators in striped bedding veins. Journal of Structural Geology, 22: 1141-1151.

Konon A. (2006) Buckle folding in the Kielce Unit, Holy Cross Mountains, central Poland. Acta Geologica Polonica, 56: 375-405.

Konon A. (2007) Strike-slip faulting in the Kielce Unit, Holy Cross Mountains, central Poland. Acta Geologica Polonica, 57: 415-441.

Konon A. (2008) Tectonic subdivision of Poland: Holy Cross Mountains and adjacent areas (in Polish with English summary). Przegląd Geologiczny, 56: 921-926.

Konon A., Mastella L. (2001) Structural evolution of the Gnieździska syncline - regional implications for the Mesozoic margin of the Holy Cross Mountains (central Poland). Annales Societatis Geologorum Poloniae, 71: 189-199. 
Kowalski W.R. (1975) Tectonics of the western end of Chęciny anticline and surrounding structures of Mesozoic margins of the Holy Cross Mts. Annales Societatis Geologorum Poloniae, 45 45-61.

Kozłowski W. (2008) Lithostratigraphy and regional significance of the Nowia Słupia Group (Upper Silurian) of the Łysogóry Region (Holy Cross Mountains, Central Poland). Acta Geologica Polonica, 58: 43-74.

Krzemiński L. (1999) Anorogenic Carboniferous sandstones from the northwestern border of the Holy Cross Mountains, Central Poland (in Polish with English summary). Przegląd Geologiczny, 47: 978-986.

Kutek J., Głazek J. (1972) The Holy Cross area, Central Poland, in the Alpine cycle. Acta Geologica Polonica, 22: 603-653.

Lamarche J., Bergerat F., Lewandowski M., Mansy J.L., Świdrowska J., Wieczorek J. (2002) Variscan to Alpine heterogenous palaeo-stress field above a major Palaeozoic suture in the Carpathian foreland (southeastern Poland). Tectonophysics, 357: 55-80.

Lamarche J., Mansy J.L., Bergerat F., Averbuch O., Hakenberg M., Lewandowski M., Stupnicka E., Świdrowska J., Wajsprych B., Wieczorek J. (1999) Variscan tectonics in the Holy Cross Mountains (Poland) and the role of structural inheritance during Alpine tectonics. Tectonophysics, 313: 171-186.

Lee Y.J., Wiltschko D.V. (2000) Fault controlled sequential vein dilation: competition between slip and precipitation rates in the Austin Chalk, Texas. Journal of Structural Geology, 22 1247-1260.

Lewandowski M. (1982) Some aspects of the tectonic history of the Holy Cross Mts in the light of palaeomagnetic studies. Acta Geophysica Polonica, 30: 261-277.

Lewandowski M. (1985) On tectonics of the Holy Cross Mts in the light of paleomagnetic studies. Publications of the Institute of Geophysics Polish Academy of Sciences, A 16 (175): 131-150.

Malec J. (1993) Upper Silurian and Lower Devonian in the western Holy Cross Mountains. Geological Quarterly, 37 (4): 501-536.

Malec J. (2001) Sedimentology of deposits around the Late Caledonian unconformity in the western Holy Cross Mountains. Geological Quarterly, 45 (4): 397-415.

Mastella L., Konon A. (2002) Non-planar strike-slip Gnieździska-Brzeziny fault (SW Mesozoic margin of the Holy Cross Mountains, central Poland). Acta Geologica Polonica, 52 471-480.

Mazur S., Aleksandrowski P., Kryza R., Oberc-Dziedzic T. (2006) The Variscan Orogen in Poland. Geological Quarterly, 50 (1): 89-118.

Means W.D., Li T. (2001) A laboratory simulation of fibrous veins: some first observations. Journal of Structural Geology, 23: 857-863.

Mizerski W. (1995) Geotectonic evolution of the Holy Cross Mts in central Europe. Biuletyn Instytutu Geologicznego, 372: 5-47.

Nawrocki J., Poprawa P. (2006) Development of Trans-European Suture Zone in Poland: from Ediacaran rifting to Early Palaeozoic accretion. Geological Quarterly, 50 (1): 59-76.

Norris D.K., Barron K. (1969) Structural analysis of features on natural and artificial faults. Geological Survey Canada Papers, 68-52: 136-157.

Noten K., van, Sintubin M. (2010) Linear to non-linear relationship between vein spacing and layer thickness in centimetre- to decimetre-scale siliciclastic multilayers from the High-Ardenne slate belt (Belgium, Germany). Journal of Structural Geology, 32: 377-391.

Noten K., van, Muchez P., Sintubin, M. (2011) Stress-state evolution of the brittle upper crust during compressional tectonic inversion as defined by successive quartz vein-types (High-Ardenne slate belt, Germany). Journal of Geological Society, 168: 407-422.

Orłowski S. (1975) Cambrian and Upper Precambrian lithostratigraphic units in the Holy Cross Mts (in Polish with English summary). Acta Geologica Polonica, 25: 431-446.
Passchier C.W. (1994) Mixing in flow perturbation: a model of development of mantled porphyroclasts in mylonites. Journal of Structural Geology, 16: 733-736.

Passchier C.W., Simpson C. (1986) Porphyroclast systems as kinematic indicators. Journal of Structural Geology, 8: 831-843

Passchier C.W., Trouw R.A.J. (1996) Microtectonics. Springer, Berlin.

Petit J.P. (1987) Criteria for the sense of movement on fault surfaces in brittle rock. Journal of Structural Geology, 9: 597-608.

Petit J.P., Wibberley C.A.J., Ruiz G. (1999) 'Crack-seal', slip: a new fault valve mechanism? Journal of Structural Geology, 21: 1199-1207.

Pożaryski W. (1978) The Świętokrzyski Massif. In: Geology of Poland, Tectonics: 216-227. Wyd. Geol., Warszawa.

Pożaryski W., Tomczyk H. (1993) Geological cross-section through SE Poland (in Polish with English summary). Przegląd Geologiczny, 41: 687-695.

Pożaryski W., Grocholski A., Tomczyk H., Karnkowski P., Moryc W. (1992) The tectonic map of Poland in the Variscan epoch (in Polish with English summary). Przegląd Geologiczny, 40: 643-651.

Price N.J., Cosgrove W. (1990) Analysis of geological structures. Cambridge University Press, Cambridge.

Racki G. (1993) Evolution of the bank to reef complex in the Devonian of the Holy Cross Mountains. Acta Palaeontologica Polonica, 37: 87-182.

Ramsay J.G. (1980) The crack-seal mechanism of rock deformation. Nature, 284: 135-139.

Ramsay J.G., Huber M.K. (1983) Techniques in Modern Structural Geology. Volume I: Strain Analysis. Academic Press, London.

Rodrigues N., Cobbold P.R., Loseth H., Ruffet G. (2009) Widespread bedding-parallel veins of fibrous calcite ("beef") in mature source rock (Vaca Muerta Fm., Neuqeuén Basin, Argentina): evidence for overpressure and horizontal compression. Journal of Geological Society, 166: 695-709.

Roo J.A., Weber K. (1992) Laminated veins and hydrothermal breccia as markers of low angle faulting, Rhenish Massif, Germany. Tectonophysics, 208: 413-430.

Samsonowicz J. (1934) Explication de la feuille Opatów. Carte Géologique Générale de la Pologne au 100 000. Varsovie.

Sejourne S., Malo M., Savard M.M., Kirkwood D. (2005) Multiple origin and regional significance of bedding-parallel veins in a fold and thrust belt: the example of a carbonate slice along the Appalachian structural front. Tectonophysics, 407: 189-209.

Suchy V., Dobes P., Filip J., Stejskal M., Zeman A. (2002) Conditions for veining in the Barrandian Basin (Lower Palaeozoic), Czech Republic: evidence from fluid inclusion and apatite fission track analysis. Tectonophysics, 348: 25-50.

Swanson M.T. (1992) Late Acadian Alleghenian transpressional deformation: evidence from asymmetric boudinage in the Casco Bay area, Coastal Maine. Journal of Structural Geology, 14: 323-341.

Szaniawski R. (2008) Late Palaeozoic geodynamics of the Małopolska Massif in the light of new palaeomagnetic data for the southern Holy Cross Mountains. Acta Geologica Polonica, 58: 1-12.

Szaniawski R., Konon A., Grabowski J., Schnabl P. (2011) Paleomagnetic age constraints on folding and faulting events in Devonian carbonates of the Kielce Fold Zone (southern Holy Cross Mountains, Central Poland). Geological Quarterly, 55 (3): 223-234.

Szczepanik Z., Trela W., Salwa S. (2004a) Upper Cambrian in the Kielce Region of the Holy Cross Mts. - preliminary report (in Polish with English summary). Przegląd Geologiczny, 52: 895-898.

Szczepanik Z, Trela W., Żylińska A., Salwa S. (2004b) Nowe kambryjskie i ordowickie jednostki litostratygraficzne w regionie kieleckim Gór Świętokrzyskich. Posiedzenia Naukowe Państwowego Instytutu Geologicznego, 61: 57-58.

Szulczewski M. (1995) Depositional evolution of the Holy Cross Mts. (Poland) in the Devonian and Carboniferous - a review. Geological Quarterly, 39 (1): 471-488. 
Szulczewski M., Belka Z., Skompski S. (1996) The drowning of a carbonate platform: an example from the Devonian-Carboniferous of the southwestern Holy Cross Mountains, Poland. Sedimentary Geology, 106: 21-49.

Tanner P.W.G. (1989) The flexural-slip mechanism. Journal of Structural Geology, 11: 635-655.

Tarnowska M. (1981) Dewon dolny w centralnej części Gór Świętokrzyskich. Przewodnik 53 Zjazdu Polskiego Towarzystwa Geologicznego: 57-68.

Tomczyk H. (1988) Tectonic movements between margin of the East-European Platform and the Holy Cross Mts region in the Palaeozoic (in Polish with English summary). Przegląd Geologiczny, 36: 9-17.

Tomczykowa E. (1993) Upper Ludlow trilobites from the southern part of the Holy Cross Mts. Geological Quarterly, 37 (3): 359-384.
Unrug R., Harańczyk C., Chocyk-Jamińska M. (1999) Easternmost Avalonian and Armorican-Cadomian terranes of central Europe and Caledonian-Variscan evolution of the polydeformed Kraków mobile belt: geological constraints. Tectonophysics, 302: 133-157.

Wiltschko D.V., Lambert G.R., Lamb W. (2009) Conditions during syntectonic vein formation in the footwall of the Absaroka Thrust Fault, Idaho-Wyoming-Utah fold and thrust belt. Journal of Structural Geology, 31: 1039-1057.

Żakowa H. (1981) Rozwój i stratygrafia karbonu Gór Świętokrzyskich. Przewodnik LIII Zjazdu Polskiego Towarzystwa Geologicznego, Kielce: 89-100.

Zakowa H., Migaszewski Z. (1995) The Carboniferous in the Holy Cross Mts. In: Guide to Excursion A2, Development of the Variscan basin and epi-Variscan cover at the margin of the East European platform (Pomerania, Holy Cross Mts., Kraków upland): 9-11. Polish Geological Institute, Warszawa. 